20. S. Parc. Self-portraits: paintings with microbiotics https://exploringtheinvisible.com/2016/09/27/self-portraits-the-microbiotic-paintings/ (Accessed 15 August 2020)

21. D. Agamben. Profanacii. Moscow (2014)

22. Dzh. Bennet. Pul'siruyushchaya materiya: Politicheskaya ekologiya veshchej. [J. Bennet. Pulsating matter: the political ecology of things]. Perm (2018).

DOI 10.15826/B978-5-7996-3081-2.48

\title{
Zombie Apocalypse in Cinema as a Form of Adaptation to New Digital Technologies and Their Consequences
}

\section{Tangalycheva Rumiya}

St. Petersburg State University, Saint Petersburg, Russia rimma98@yahoo.com

\begin{abstract}
The article is devoted to the analysis of the film "Train to Busan" by South Korean film director Yeon Sang-ho, which depicts the situation of a zombie apocalypse after a chemical leak from a scientific laboratory. The director focuses on the reaction of representatives of different strata, groups and social institutions of society to the tragedy. Ultimately, the film's ideology leads to a dilemma between capitalist efficiency and social justice. These subjects are analyzed in the article from the positions of sociological approaches and concepts.

Keywords: cinema, sociology, Apocalypse, technogenic threats, future discourse, economic efficiency, social justice

\section{Introduction}

In 2016 was released the movie "Train to Busan" filmed by South Korean director Yeon Sang-ho. The film received huge box office worldwide and became the highest-grossing Korean film in Malaysia, Hong Kong and Singapore. It also received positive critical reviews. On Rotten Tomatoes, the film has a rating of $94 \%$ based on 115 reviews with an average score of 7.6 out of 10. On Metacritic, the film has a score of 72 out of 100 based on 16 critics reviews, which meets the status of "generally positive reviews".
\end{abstract}


In Russia, the film also got high assessment from film critics and viewers. Some Russian critics saw the film as a social parable about how to react to mass insanity [Dolin, 2016], and one of them considered the zombie-virus as "straightforward political metaphor" [Nechaev, 2016], well understood by participants of mass protests in South Korea in 2016.

The action takes place during a zombie apocalypse in a high-speed train on the road from Seoul to Busan. During the departure of the train, zombies appear at the station, attacking people. A girl bitten by a zombie manages to jump into the last car. She quickly spreads the infection throughout the whole train. The heroes are forced to escape from zombies, and in such an extreme situation the and the inner essence of each character are revealed. In the film, the director presents a gallery of social types from various walks of life with their attitudes and orientations, as well as shows their psychological changes in the face of a deadly threat. Each of them react to the disaster in their own way. While the main force of the film is reflected in the humanity of the story: the father protects a little daughter, husband - wife, boy - girl, older woman - sister, and the viewer throughout the entire film is desperately worried about them. The relevance of the story is due to the technogenic risks and threats that are caused by technological progress, on the one hand, and the lack of rationalization of the "life world" of a person, on the other. Y. Habermas called this process "the pathology of modern life" [Habermas, $1986,96]$. We see similar situations everywhere in modern society. However, one of the most unusual and powerful events affecting people's consciousness and behavior was the Coronavirus pandemia, announced by the world health organization on March 12, 2020. It changed the normal functioning of social institutions and the usual daily practices of people in all over the world.

The key focus of the research is a sociological analysis of the zombie apocalypse as an image of the future in modern society on the example of "train to Busan". For theoretical sources for the interpretation of the storyline and discourses were chosen W. Beck's sociological concept of Risk society, M. Buravoy's concept of public sociology and scientific hypotheses, and of the capitalism future supposed by I. Wallerstein, R. Collins, M. Mann, and others. In order to understand how artistic and theoretical constructs are transformed into social reality, we investigated a series of interviews and reviews of this film published in the Russian and foreign press. 


\section{Content analysis of the film "Train to Busan"}

The film symbolically begins with a check on the road and information that in a certain scientific laboratory there was an incomprehensible leak. The truck driver, expressing dissatisfaction with the constant checks, tries to answer the phone and knocks down a moose on the road. Thinking that the animal is dead, he nevertheless leaves. But the bloodied moose rises to life as a zombie animal.

After that the plot starts, all major events of which were subjected to content analysis. For content analysis were selected such observation units as the main characters of the film, the number and content of key episodes with their participation. Usually, the timing of key episodes and the total number of appearances in the frame of the main characters are still highlighted, but since the film "Train to Busan" is an action thriller, it is difficult to track the timing and total number of appearances in the frame: all the characters constantly appear in the frame, fleeing from zombies or fighting them.

Counting the number of key episodes, we see that the main character of the film is Seok-woo, a fund manager - successful and productive. As usual, he sacrifices the interests of the family for the sake of work and, being divorced, lives with his mother and daughter. And everything would have continued like this if what Bakhtin has called menippea (after the third-century BC philosopher Menippus of Gadara) hadn't happened. Describing this genre, Bakhtin emphasized such features of menippea as the combination of creativity (in this case, directed by Yeon Sang-ho) with the formulation of deeply ideological problems. Bakhtin gave the following methodological description of the menippea in a work of art: it is a moral and psychological experiment, a violation of the normal course of events, the creation of exceptional situations that demonstrate and provoke opinions and ideas [Bakhtin, 1979]. During this experiment, the main character's personality are transformed, values are re-evaluated, and what is called "redefinition of the situation" in phenomenological sociology. At first, Seok-woo tries to use his special status to use insider information and get support from his "friends" at the stop in Daejeon. However, later, insider information from the same source opens Seok-woo's eyes: he is informed that the commercial activities of their company have led to a disaster in the country. In the face of a deadly threat, he realizes that the main value in his life is his daughter and tries to save her in every possible way. When he has got the infection, he remembers the images of his newborn daughter and then he experiences happiness. 
The antipodes of Seok-woo are the negative character Young-seok and the positive character Sang-hwa. Sang-hwa, who patiently takes care of his capricious pregnant wife Seong-kyeong, shows himself as a brave hero, helping not only his wife, but also the rest of the passengers, including Seok-woo and his daughter Su-an. He bravely fights with zombies, endlessly covering other people. This hero does not have a moral dilemma - he is, although simple, undoubtedly, a purely positive character. In contrast, the Director of the company Young-seok is depicted, who saves himself until the very end, while constantly receiving insider information and giving orders to the train chief not to wait for other people, to leave immediately. He "goes over the heads", throwing other characters of the film to the zombies: the conductor, the girl cheerleader of the baseball team, and finally, the train chief himself. It is not difficult to notice the collective images of the main characters: at one pole we see the reaction to the emergency situation on the part of the basic, inconspicuous layers of society (ordinary workers and employees) and at the other - the behavior of the elected (officials and high-ranking leaders).

Other characters in the film - young baseball players, a homeless man, two elderly women - are depicted in the film, rather, as social types that complement the previous characters and shows the variety of social stratification in modern society.

Yeon Sang-ho, answering the question why the film became so popular, says that he tried to combine in his film such extraordinary elements as zombies, on the one hand, and the most ordinary people from our usual life in all their diversity - people of different ages, genders, social statuses - on the other. He wants to draw a portrait of modern society At the same time, the Director keeps a moral neutrality, mentioning that he did not intend to portray Seokwoo or Sang-hwa as heroes, and Young-seok as the devil. Just the first saved their relatives, and the second - was afraid to die, helping others. The Director highlights the behavior of ordinary people in a emergency. Only representatives of the future generation, $\mathrm{Su}$-an and Seong-kyeong, who is about to give birth to a child, manage to escape. By completing the film in this way, the director seems to give the future to the next generations. He poses the central question of his movie - What kind of future will we leave to our children?

Describing the plot, it is impossible to miss two important things. The zombies, who are the most recent to appear in the movie and news information coming from official authorities on television and in the form 
of appeals to passengers. After watching the movie, it becomes obvious that for the film director, the relationship between the characters is much more important than the theme of zombies, which are only the personification of a threat in the modern world. At the same time, the director is quite focused on the detailed image of zombies - how they look, move, how their facial expressions and eyes change. Many Russian and foreign critics drew attention to the high professionalism in the image of the creators of the film zombies[Trofimenko, 2016]. All this, of course, made the film attractive to the viewers and contributed to the box office success.

A special theme in the film is the news and information from official authorities. The reality of the present time is that true events do not always correspond to the news agenda. Today we are flooded with information that contradicts itself. In the movie "Train to Busan", once we hear from the screen that there are outbreaks of violence in the city, but the military takes measures to restore order. Another time it turns out that a number

of provinces were overwhelmed by a wave of violence, rioters tried to destroy state property, and there was imposed a state of emergency. Then there were announcements about the elimination of the main hotbeds of violence, a request to remain calm and trust the government. In addition, train passengers were misinformed when they were told that the government was in control of the situation in Daejeon and everyone should get off. Meanwhile, Seokwoo received insider information that those who got off the train will go to quarantine. The topic of information communication is extremely relevant to the evaluation of this film and partly helps explain its box office success: the government is portrayed sarcastically, because it cannot cope with current events. Recall that in December 2016 President of the Republic of Korea Park Geun-hye was impeached, and on the eve of mass popular protests against bribery, abuse of power, and the transfer of secret information to people far from the government. However, it is certainly possible to interpret the news agenda in the film in a broader way: literally in all societies today, we see an ideological disparity of information sources that form a literally paranoid picture of what is happening in the minds of ordinary people who do not trust official sources of information, they act with their own ideas and values.

\section{Discourse of the future in cinema and sociology}

The genre of films about the end of the world is not new in the world of cinema, fiction, computer games and is always a kind of prediction 
of the future, often inevitable and tragic. Common themes of apocalyptic movies are:

- alien invasion ("War of the Worlds", "Independence Day", "Star Wars", animated series "Transformers", "the Fifth Element"),

- displacement of humans by living creatures of a different kind ("Reign of Fire", "Planet of the Apes", "Rats - Notte di terrore", "Parasite"),

- viruses, epidemics, pandemics ("Land of the Dead", "Dance of the Dead", "I am Legend", "Resident Evil"),

- mutinous artificial intelligence ("Matrix", “Terminator", "Screamers", "Steel Dawn", "Cyborg"),

- nuclear war ("Mad Max 2, 3", "the Postman", "Mutant Chronicles", "On The Beach")

- natural disasters ("Asteroid", "Armagedon", "Night of the Comet", " Until The End Of The World", "El Largo Invierno", "Category 6: Day of Destruction", "After the Apocalypse"), etc.

In general, we can identify the following plot areas of this genre: a) natural, "natural" disasters; b) man-made disasters, human intervention in the laws of nature; C) intervention of an external, most often reasonable, force [Poryadin, 2009].

The Apocalypse is usually understood as the process of the collapse of the world, the End of the World, is reflected in the legends and myths of different peoples of the world. They provide a variety of descriptions of how the world will disappear, be swallowed, burn, freeze, sink, or be destroyed in other ways. There are many scientific and religious hypotheses about the end of the world. What in the past centuries was seen as the causes of the Apocalypse has lost its significance, but there are appearing new ways and means of expressing this.

We consider that it is appropriate to refer to the theories and ideas of modern sociologists in order to present their vision of the future and how it resonates with the image of the future in modern art forms, especially in cinema. The major part of sociological research is conducted as a description and explanation of the present - social phenomena observed in the "here and now" mode. However, the object and subject of sociology are diachronous: the object of sociology is the present, but its subject is the future. In contrast to modern futurology, which focuses on the technological perspectives of humanity, on (post) human genetics and demography, climate and ecology, the subject of sociology is not the fate of humanity, but the social future: 
social structures and ways of social interaction that are relevant in the long term [Ivanov and Asochakov, 2016].

In July 2016 in Vienna a forum of the International Sociological Association (ISA) "the Future we want: global sociology and the struggle for a better world" was held. The main idea of the Congress was expressed in the program report of forum President Markus Schultz. His report was based on the idea that sociology was initially driven by a collective reflection on the possibility of change and now, in the context of global trends and the rise of new social movements, it must move from an objectivist vision based on determinism and "expert democracy" to engaging in public debate and focusing on an "open and contested" future [Shulz, 2016].

The social future as a subject of study has returned into the recent years' sociology in the form of conceptualization of risks and social chaos. For example, the German sociologist W. Beck linked the concept of risk with the stages of society modernization. According to his theory simple modernization was associated with the risk of detraditionalization and the formation of new institutions of industrial society for that time. The second wave of reflexive modernization, which began around the 1960s, led to the discovery of "side effects" of economic progress in the form of the nuclear war threat, terrorism, environmental pollution, global warming, global diseases such as AIDS, and now the coronavirus pandemia. Modern development is associated with risks of individualization, revision of gender relations, and global economic risks. Economic risks are associated with the fact that technological advances, robotics and computerization lead to the removal of people from the labor sphere, transferring them to flexible forms of employment with low wages and lack of social guarantees. If the main value of industrial society was equality, then in modern society, security becomes the main value: people see that the state is not able to cope with new threats and begin to independently look for ways to deal with the risks to their lives [Beck, 1999; Beck, 2000; Beck and Beck-Gernsheim, 2002].

Beck's concept of a risk society resonates well with the events of the film "Train to Busan", where an unknown infection is spread from a scientific laboratory and leads to the transformation of people into zombies. In these conditions, each passenger has to find his own way out of the situation and escape from the zombies. Against the background of elements of fantasy entertainment and keeping the audience's attention with a sharp, exciting story, Yeon Sang-ho raises political and ideological issues related both 
to the survival of humanity and to the personal safety of the environment. And in this, also, you can find the secret of the popularity of his film, which is the speaking of the situations that cause anxiety for every viewer. One of the Russian film critics even hypothetically draws parallels to the situation in the high-speed train going from Seoul to Busan in Korea, with the highspeed train "Sapsan", which regularly runs from Moscow to St. Petersburg in Russia [Zelvensky]. In this sense, the film “Train to Busan” performs an important social function of informing the audience about how to behave in unexpected dangerous incidents.

The logic of the research on social activism, which opens up the prospect of a better future, was initially put forward via the movement for "public sociology", initiated by M. Buravoy [Buravoy, 2005]. Public sociology strives to spread sociology beyond the academic framework and distribute its ideas among a broad audience. Buravoy and other scientists who promote these ideas push the development of sociological science towards involving issues related to public activities, political activity, social movements, and civil society institutions in open public and political spheres. If a movement associated with public sociology is possible, it should breathe new life into sociology by using its empirical methods and theoretical ideas to discuss not only what is currently happening in society, but also what society could become. Public sociology assumes a normative approach to analysis and the political nature of the analysis of social reality [Ivanov and Asochakov, 2016].

The social future is an intense present. In other words, these are not the institutional structures and patterns of interaction that are widespread and stable in the present, but only those processes that cause instability, mobility and gaps in social life. Therefore, the tendencies to protest and challenge the most disadvantaged groups and structures of society, objectively being on the periphery of social life and, consequently, on the periphery of attention in the study of the social present, in the study of the social future, should become the Central object, placed at the center of attention.

Followers of the theory of social actionalism in the 1970s participated in the activities of social movements, including extremist ones, applying the method of social intervention in practice. The same idea, but in a less radical form, is found in Buravoy and followers of his concept of "public sociology", who turn to the practices of civil activism and protest movements that spread in the period after the global economic crisis of 2008 [Ivanov and Asochakov, 2016]. 
If a well-made movie, using a simple language accessible to ordinary people, can attract millions of viewers from various countries and make them think about important problems of our time, then social science is limited in capabilities by the University audience. At the same time, the art of cinema becomes popular at the peak of current trends, political events and fashion, while the product of social science has a longer life span and affects the most intellectual part of society. Nevertheless, public discourses of cinema and social science have a great potential to influence discursive and practical consciousness in modern society [Giddens, 2005] and form the cognitive and emotional attitudes and behavioral orientations of millions of people in different countries.

\section{The discourse of the future of capitalism: productivity and material success}

In an interview, the director of the film answering the question - why does he give up hope at the end of the film? - says: "I didn't give an obvious ending to the film" ["Busan" director reflects on film's wild ride]. Moreover, it is not entirely clear how the Busan military in camouflage will be able to hold the defense against the zombies that flooded the country; the director suggests that the audience independently imagine the ending. The last survivors are represented by the future generation - a little girl Soo-an and a pregnant woman who is about to give birth to a child. Developing the main storyline of the film - the relationship between Seok-woo and his daughter. Director Yeong Sang-ho wonders: "What can we pass on to the next generations? Until now, we have valued development - economic, social - in the hope that our children will live better. However, development itself may one day stop. Even today, we can say that development does not always make sense. In this case, what should we pass on to the next generations?" ["Busan" director reflects on film's wild ride].

In an attempt to answer this question, we turn to sociological works that assess the future as an economic system of production and distribution. Capitalism is primarily associated with the goals and ideals of enrichment, and although it is the cause of many of the ills and misfortunes of modern society, it still has no worthy alternatives. The analysis of the future of capitalism is given, for example, in the book "Whether there is a future for capitalism?" - a collection of articles by famous sociologists I. Wallerstein, R. Collins, M. Mann, G. Derlugyan, K. Calhoun [Whether there is a fu- 
ture for capitalism, 2015]. The authors are trying to determine the changes of a present, describing it in terms of "neo-liberalism", "post-industrialism", and "post-Fordism", "postconsumer" etc., and what are the effects of globalization on companies. They are convinced that there is a crisis in the world in general and in particular societies. Due to this fact, sociologists interpret the future of capitalism in different ways.

For example, I. Wallerstein in the article "Structural crisis, or Why capitalists can consider capitalism unprofitable?" relies on the traditional premise that capitalism, like any other system, has its own life span. He writes that today the debate about the structure of the new macro system is based on two alternative ideologies: the spirit of Davos (named after the world economic forum in Davos, Switzerland) and the spirit of Porto Alegre (named after the world social forum in Porto Alegre, Brazil). Supporters of the Davos spirit suggest tough measures to preserve the old capitalist order, but there are widespread ideas in their ranks that repression does not always work in the long term and it is necessary to improve capitalism, fertilizing it with ideas of green movements or social justice. Supporters of the spirit of Porto Alegre, who advocate the ideas of equality and justice, also do not agree in their approaches and are divided into those who develop discussions in the direction of consensus based on discourses of the civilizational crisis, as well as irrational enrichment and consumption, and those who openly call for a political struggle for power, insisting on the redistribution of all available benefits and opportunities [Wallerstein, 2015].

R. Collins in the article "The Middle class without work: exits are closing" characterizes technological substitution as a new threat to capitalism. If earlier mechanization replaced mainly manual labor, now new technologies are able to displace many professions and types of employment of people with intellectual labor. It lists possible threats:

- the appearance of online stores, online publications, etc. does not create new jobs, but, on the contrary, displaces previously employed employees;

- computer technologies allow you to conduct business remotely from anywhere in the world, which leads to increased competition among specialists and managers with modern business education in developed countries;

- financial transactions in pension funds, exchange-traded investments and speculation, which are popular among the middle class, are becoming increasingly risky, as financial markets can burst at any moment; 
- administrative work in the public service can also be reduced by 3-5 times or more in the context of an employment crisis, since, on the one hand, business owners are growing dissatisfied with high taxes, on the other hand, the unemployed and part-time employees who have a high level of education and are able to quickly mobilize if necessary to organize a protest movement are protesting;

- an inflation of diplomas, the value of which decreases as the number of University graduates increases (now $60 \%$ of young people study at universities, and in the Republic of Korea $-80 \%$ ). This process is fraught with high competition for prestigious jobs and alienation of young people from the official standards of adulthood. Collins writes that the knowledge economy is a myth, and education in today's conditions is a hidden Keynesianism: cheap student loans are simply a mechanism for distributing hidden social benefits and state subsidies. According to the author, there are various ways to solve this problem: from cheaper education through the introduction of online courses to technological substitution in the field of education itself, and even mass protests against high education costs, as was the case in 2010 in the United States [Collins, 2015, 64-91].

The sociologist also notes the unevenness of technological substitution in different societies: if in the United States and Western Europe, technological substitution will affect the middle class, then in China, India and Brazil it will not be as deep. The crisis of capitalism will increase if it joins other protest movements (religious, racial, ethnic) for the distribution of official positions and rents, state regulation, and access to resources for ethnic groups (positive discrimination).

M. Mann in the article "The End may be near, but for whom?" expresses a much more optimistic point of view. He believes that by 201 many countries had overcome the crisis. Among the structures that proved to work were corporatist "development States" like South Korea, development-oriented economies in East Asia, where the ideology of neoliberalism did not become widespread, or countries where strict regulation of financial capital remained (Canada).

Mann believes that the future of capitalism will most likely be "not stormy, but rather boring" (about one percent growth per year) [Mann, 2015, 145] and there are no alternatives to capitalism, since fascism and communism have proved ineffective and unattractive, and fundamentalism stands for spiritual salvation rather than material salvation. Therefore, we need a turn towards 
greater state regulation, curbing national States, and increasing the rights of citizens. If this does not happen, then there will really be a catastrophe: the relatively privileged and rich States of the North will build fortresses of "siege capitalism" and "ecofascism" against the rest of the world, and the main motive of such societies and people will be anger [Mann, 2015, 153].

The director of the film "Train to Busan" can be considered a continuation of the social problematics of the revolutionary zombie discourse.

In this regard, we can recall one of the first Korean zombie films "Pulgasari” (불가사리 — cor., or "iron eater" — in late Korean mythology, a legendary animal with the body of a bear, which has an elephant trunk, buffalo eyes, a cow's tail and tiger paws. It feeds on iron, and also banishes delusions and nightmares in people). The image of Pulgasari in Korean folklore has been known since the Koryo period in the 10th-14th centuries. The film "Pulgasari” was filmed by South Korean director Shin Sang-ok in 1985 in the North Korean genre of science fiction action. Shin Sang-ok was abducted by North Korea's security services on the direct instructions of Kim Jong-Il and worked for years as a forced laborer for the North's propaganda cinema. Some sources later referred to this film as "Communist Godzilla" [Gorenfeld, 2003]. The film "Pulgasari" also depicts a direct allusion and criticism of capitalism as a political and economic system that ripens in the bowels of feudalism and destroys it due to the irrepressible consumption of resources. An additional ideological moral put forward by the film's producer, Kim Jong-Il, is the idea of a people's revolution.

Yeon Sang-ho develops this topic in a very different context. If the North Korean film of 1985 depicts the traditional criticism of capitalism, then in "Train to Busan" we see the activities of large multinational companies, financial pyramids that conduct highly effective activities without any social responsibility. In this regard, recall the episode of the insight of the main character Juice: while the blood of the passengers splashes on the glass of cars, TV broadcasts about the strike developed into a rebellion, and the introduction of martial law to suppress anti-state conspiracy, it covers the guilt for his financial fraud, as he speculated in shares of the company, prevent the leak of classified infection which turns the Korean zombie.

This episode reveals the violation of social order and law in modern society and attracts the attention of the British sociologist Z. Bauman. He writes that in the modern world, some structures are moving faster, such as the economy and business. Multinational corporations in the pursuit 
of profit are developing at a great speed and strive to completely eliminate spatial restrictions (complete overcoming of gravity). Only in the most egregious cases do corporate crimes end up in court and become public knowledge [Bauman, 2004]. Prisons are filled with people from the lower class of society who have committed so-called "traditional crimes", such as, for example, the stowaway train ride of a homeless passenger in the film we are analyzing.

The main character of the movie Seok-woo before the disaster was a typical high-ranking manager, in the terminology of another character Sang-hwa, a man living in a dog-eat-dog world. It is for such highly paid managers that the practical philosopher Andrew Taggart conducts his training programs [see Taggart, 2018].

Then arises the question: why is one of the main idols these days Elon Musk, especially for those who work in the IT industry? The practical philosopher believes that the answer to this question is related to the concept of "the era of the bourgeoisie", which means a gradual shift in public consciousness that began around the XIX century. The "bourgeois era" consists of several stages.

- The bourgeois paradigm and the revaluation of values (since the beginning of the XIX century). The old values of the aristocrats - honor, pride, as well as Christian values - compassion and piety - are gone. They began to be replaced by bourgeois values - prudence, restraint, the ability to earn trust and honesty in transactions. The aristocrats honored heroes, the Christians honored saints, the bourgeois honored practical entrepreneurs, and most of all, visionaries like Steve Jobs and Elon Musk. The re-evaluation of values has led people to judge themselves and others by how they earn a living.

- Society of labor (from 1945 to the present). After the second world war, a different process began: the gradual transformation of people into workers, when work takes up an increasing part of life. The post-world war II period was marked by economic growth. For example, many middle-class Americans could afford their own homes, comfort, and technological innovations. They began to separate leisure from work and were able to retire safely. Watching the well-being of their parents, representatives of "generation X" and later "generation Y" believed that their prospects were even better. Formally, people in the United States work less today than in the 19th century: the working week has decreased from 70 hours in 1830 to 40 hours by now. But the numbers do not reflect the quality of the work that has become the foundation of our social identity. 
- The threat of technological unemployment (our possible future). This stage is associated with the development of artificial intelligence and machine learning. The result of these processes may be unemployment in the transport industry, manufacturing, services, and other areas. Does this mean that people will feel like a "useless class" and generally useless people?

Taggart writes that modern people find in personal productivity salvation from suffering, happiness, or at least something that gives them a chance to be happy. But this is an illusion. The goal of productivity is to preserve the labor society. There will be no need for labor, and the idea of productivity will be devalued.

In addition, each of us strives to overcome the emptiness of his life, the vacuum that arises if it is not filled with work. That is why life hacking has been so popular in social networks in recent years: it is easier to solve simple tasks than to answer important, complex questions related to the meaning of our existence. These questions are philosophical in nature: who am I? what is the meaning of life? The labor society, with its constant employment and race for productivity, distracts us from thinking about these issues [Taggart, 2018].

The director of the film "Train to Busan" is looking for answers to these questions and finds them in his own way. In our opinion, the general message of the film Yeon Sang-ho leads the audience towards is the idea of love. We see how in the face of death, the film's characters make a moral choice in favor of their loved ones: Seok-woo jumps from a train to save his daughter Su-an; Sang-hwa is killed in a fight with a zombie while rescuing his wife Seong-kyeong; an elderly woman voluntarily goes out to her infected sister, wanting to thank her one last time; Yong-gook does not want to run away from the zombies without his beloved Jin-hee, preferring to die in her arms; homeless also brings their lives in sacrifice, giving the possibility to run the giving the possibility to run the Su-an and Seong-kyeong in order to win time for. Even the Director of the company, Yong-seok, in the last moments of his life, remembers his childhood and his mother, who probably loved him more than anyone in his life. Indeed, if you believe the findings of modern psychologists, there are almost no people who, in the face of death, think that they had not worked enough.

\section{Conclusion: alternative scenarios for the future}

The plot of the film makes the viewer remember another vivid South Korean Thriller "Snowpiercer", shot in 2013 by Director Bong Joon-ho and 
showing the lives of survivors on a train after a global cold snap. Both pictures show post-apocalypses on the train, but it is a meaningful example of antagonist films [Nechaev, 2016]. Bong Joon-ho made a complex movie, where the train rushing on an icy planet represented a metaphor for human society - with its social injustice and division into classes. At the tail of the train are the social lower classes, who are fed protein biomass from processed beetles by the fascist dictatorship and are reminded of their place with a system of harsh punishments at every opportunity. A bloody revolution was beginning with the gradual advance of the humiliated and insulted to the locomotive and yet, the film "Snowpiercer" only at first seems to be a picture with a left-wing bias and a desire for justice through revolution. In the finale of the film, everything is turned upside down. It turns out that the system itself planned a bloody riot in order to reduce the excess number of passengers from the point of view of life support. The creators of "Snowpiercer" are clearly skeptical of both the revolutionary pathos and the possibility of a positive scenario for the survival of mankind.

In the film "Train to Busan", the reasons for the zombie apocalypse are not directly mentioned, but the replicas can be understood that it is the "sharks of capitalism" who were ready to sacrifice the interests and security of society for profit, financing dangerous scientific developments. The director insistently pronounces the main idea of the work - you can survive and win only by rallying and forgetting about selfish aspirations. The almost cartoonish villain Yong-seok, a businessman with connections who is literally ready to walk over corpses to stay alive, helps illustrate the message.

By the end, we see that after the death of the main character Seok-woo, only his daughter $\mathrm{Su}$-an and a pregnant Seong-kyeong remain alive. The locomotive, in which they were left alone, rushes through green fields and forests. In the frame, we see a blooming beauty filled with life. There are protective structures on the tracks. The locomotive stops, the two heroines go through a tunnel, through piles of corpses and bonfires. The city is guarded by the military, who first receive orders to eliminate Su-an and Seong-kyeong , but then, after hearing the children's singing of Su-an, decide to save them. The command comes: "Cover them!" In these simple words, you can hear the warmth of the human mind, acting not as a programmed machine, but relying on feelings and emotions. And although we don't know if Busan will eventually be able to resist the zombies, thanks to the creators of the film, the audience is given hope for salvation, kindness and common sense. 
We become witnesses of two possible outcomes in Korean apocalyptic films. In both pictures, in fact, only children who take the baton from adults survive. What is their future? In the first film "Snowpiercer" - death among the snow and polar bears. In the second - the hope of reuniting with people and meeting with the mother. And their path to hope, to a better future, as we have seen, is not obvious. It is not necessary that it will be associated with irresponsible capitalism or, conversely, with revolutions and the destruction of the capitalist structure of society. However, in any case, the future, according to both sociological concepts and the idea of Director Yeon Sang-ho, should be associated with active collective actions of people towards creating a just and safe society. In the terms of Habermas, "new technologies force us to conduct a public discourse about the correct understanding of the cultural form of life. And philosophers no longer have any plausible pretexts to leave the subject of this discussion at the mercy of representatives of the biological sciences and science fiction-inspired engineers" [Habermas, 2002, 26].

\section{Acknowledgment}

This work was supported by the Core University Program for Korean Studies through the Ministry of Education of the Republic of Korea and the Korean Studies Promotion Service of the Academy of Korean Studies (AKS-2016-OLU-2250002)

\section{References:}

1. Rotten Tomatoes: https://www.rottentomatoes.com/m/train_to_busan (Accessed 25 August, 2020).

2. Metacritic: https://www.metacritic.com/movie/train-to-busan (Accessed 25 August, 2020).

3. A. Dolin. "Poezd v Pusan": sotsial'naya pritcha o zombi-apokalipsise ["Train to Busan": a social parable about Zombie Apocalypse]. https://radiovesti. ru/brand/61178/episode/1436393 (Accessed 25 August, 2020).

4. A. Nechaev. Levyi marsh. Novoe nashestvie zombie v uizhnokoreiskom trillere "Poezd v Pusan" [Left March. New zombie invasion in the South Korean Thriller “Train to Busan”]. Rossiyskaya Gazeta. № 7138 (270). https://rg.ru/2016/11/28/ poezd-v-pusan-stal-samym-kassovym-blokbasterom-v-istorii-iuzhnoj-korei.html (Accessed 25 August, 2020).

5. J. Habermas. Autonomy and Solidarity: Interviews. Peter Dews (ed.). Verso, London (1986). 
6. M.M. Bakhtin. Estetika slovestnogo tvotchestva [Esthetics of verbal creativity]. Iskusstvo, Moscow (1979)

7. "Busan" director reflects on film's wild ride: Yeon Sang-ho's first live-action movie was a historic success - so why is he still worrying? http://koreajoongangdaily.joins.com/news/article/article.aspx?aid=3022477 (Accessed 25 August, 2020).

8. M. Trofimenko. U Korei propezalis' zombie [Korean zombies emerged]. Kommersant (2016) https://www.kommersant.ru/doc/3150089 (Accessed $25 \mathrm{Au}$ gust, 2020).

9. I. A. Poriydin. Konech sveta kak mechta, ili sindrom apokalipsisa [the End of the world as a dream, or the syndrome of the Apocalypse]. Vestnik SamGU [Bulletin of the Samara state University]. № 1 (67) (2009), pp. 93-100

10. D. Ivanov, U. Asochakov. Buduzhee kak predmet sotsiologii [The future as a subject of sociology] Teleskop journal, № 3 (117) (2016), pp. 15-21

11. M. Schulz. Debating futures: Global Trends, Alternative Visions, and Public Discourse. International Sociology. № 1 (2013), pp. 3-20.

12. U. Beck. World Risk Society. Polity Press, Cambridge (1999).

13. U. Beck. Brave New World of Work. Polity Press, Cambridge (2000).

14. U. Beck, E. Beck-Gernsheim. Individualization: Institutionalized Individualism and its Social and Political Consequences. Sage, London (2002).

15. S. Zel'venskiy. "Poezd v Pusan" - koreiskiy blokbaster o zombi-apokalipsise. Petsenziya na hil'm ["Trains to Busan" is a Korean blockbuster about a zombie Apocalypse. Film review] https://daily.afisha.ru/cinema/3724-poezd-v-pusan-koreyskiy-blokbaster-pro-zombi-apokalipsis/ (Accessed 25 August, 2020).

16. M. Burawoy. For Public Sociology. American Sociological Review, Vol. 70 (2005), pp. 4-28.

17. A. Giddens. Ustroenie obzhestva: Ocherk teorii structuratsii [Organization of society: Essay on the theory of structuration.]. Akademicheskiy proekt, Moscow (2005).

18. Is there a future for capitalism? Collection of articles by I. Wallerstein, R. Collins, M. Mann, G. Derlugyan, and K. Calhoun. Gaidar Institute publishing house, Moscow (2015).

19. I. Vallerstain. Structurnyi krizis, ili Pochemu kapitalisty mogut schitat' kapitalizm hevygodnym. Est' libuduzheeukapitalizma? Sb. statey I. Vallerstaina, R. Kollinza, M. Manna, G. Derlug'yana, K. Kalhuna [Wallerstein I., the Structural crisis, or Why capitalists can consider capitalism a disadvantage. Is there a future for capitalism? Collection of articles by I. Wallerstein, R. Collins, M. Mann, G. Derlugyan, and K. Calhoun]. Gaidar Institute publishing house, Moscow (2015), pp. 23-60. 
20. R. Kollinz. Sredniy klass bez raboty: vyhody zakryvaiutsya. Est' li buduzhee u kapitalizma? [Middle class out of work: exits are closing. Is there a future for capitalism? Collection of articles by I. Wallerstein, R. Collins, M. Mann, G. Derlugyan, and K. Calhoun]. Gaidar Institute publishing house, Moscow (2015), pp. 61-112.

21. M. Mann. Konets, mozhet, i blizok, tol'ko dlya kogo? Est' libuduzheeukapitalizma? Sb. statey I. Vallerstaina, R. Kollinza, M. Manna, G. Derlug'yana, K. Kalhuna [The end may be near, but for whom? Is there a future for capitalism? Collection of articles by I. Wallerstein, R. Collins, M. Mann, G. Derlugyan, and K. Calhoun]. Gaidar Institute publishing house, Moscow (2015), pp. 113-155.

22. J. Gorenfeld. The producer from hell. Guardian (2003).

23. Z. Bauman. Globalizatsiya: posledstviya dlya cheloveka i obzhestva [Globalization: implications for people and society]. Moscow (2004).

24. A. Taggart. We're All Bourgeois Now: The Story of our 200-year-old Obsession with Personal Productivity. https://medium.com/@andrewjtaggart/were-allbourgeois-now-the-story-of-our-200-year-old-obsession-with-personal-productivity-e178bbce766b (Accessed 25 August, 2020).

25. J. Habermas. Buduzhee chelovecheskoy prirody [the Future of human nature.]. Ves' mir, Moscow (2002).

DOI 10.15826/B978-5-7996-3081-2.49

\title{
Creativity in the Film Director's Work: An Example of Works by A. Zvyagintsev
}

\author{
Temlyakova Alina \\ Ural Federal University, Ekaterinburg, Russia \\ ateml@mail.ru
}

\begin{abstract}
This article discusses the main approaches to the definition of creativity, including interdisciplinary ones; in addition, the author highlights a systematic approach to the definition and understanding of creativity at the intersection of psychology, philosophy, and economics. The author reveals the specifics of the analysis of the filmmaker's work through the prism
\end{abstract}

